\title{
RELAPSE OF GONORRHOEA AFTER TREATMENT WITH PENICILLIN OR STREPTOMYCIN*†
}

\author{
BY \\ A. J., EVANSt \\ St. Thomas' Hospital and University College Hospital, London
}

The earliest workers with penicillin observed that it was extremely effective in vitro against the gonococcus. Florey and his co-workers (Abraham, Chain, Fletcher, Gardner, Heatley, Jennings, and Florey, 1941) found the gonococcus to be the most sensitive of a wide variety of pathogens they tested against penicillin. Clinical experience supported laboratory findings, and penicillin became, and has remained, the drug of choice in the treatment of gonorrhoea (Reyn, 1961). Claims for the success of streptomycin in the treatment of gonorrhoea were never as enthusiastic as for penicillin : early laboratory work (Miller and Bohnhoff, 1946: Love and Finland, 1955) showed that most strains of gonococci were sensitive to streptomycin in vitro, but Moore (1949) suggested that only 90 to 95 per cent. of patients were cured by it.

In 1958 several papers were published, notably those by Cradock-Watson, Shooter, and Nicol (1958) and by Curtis and Wilkinson (1958) in Great Britain, reporting the occurrence of numerous strains of penicillin-insensitive gonococci. Thereafter such strains, and the failure of standard doses of penicillin and of streptomycin to cure gonorrhoea, have been widely reported, not only in the United Kingdom but throughout the world.

This paper reports a clinical assessment of the recent incidence of relapse of gonorrhoea after treatment with penicillin or streptomycin. Particular attention has been directed to correlating these clinical results with the results of published laboratory studies.

\section{Material}

All the male patients with gonococcal urethritis attending the Venereal Disease Clinics at St. Thomas' Hospital, University College Hospital, and St. Bartholomew's Hospital during 1962-63 have been studied. At each hospital initial diagnosis of gonococcal urethritis was

* Received for publication April 28, 1966.

$\dagger$ Much of this work formed part of a thesis accepted by the University of London for the M.D.

A preliminary account of some of these results was given in a short paper read to the M.S.S.V.D. on March 20, 1964.

$\ddagger$ Present address: Plymouth General Hospital, Freedom Fields, Plymouth. made by finding Gram-negative, intracellular, reniform diplococci in smears of the urethral discharge stained by Gram's stain. Cultures were not taken routinely on first attendance.

Treatment Routine.-At St. Thomas' and St. Bartholomew's Hospitals routine treatment for gonococcal urethritis was a single intramuscular injection of 600,000 units of an aqueous suspension of procaine penicillin. At University College Hospital a single intramuscular injection of $1 \mathrm{~g}$. streptomycin, or $1 \mathrm{~g}$. on 2 successive days was used.

Surveillance.-At all three hospitals patients were seen 1 or 2 days after treatment, when a urethral smear was examined for gonococci, and a two-glass urine specimen inspected for macroscopic debris. If no gonococci were seen in the stained smear, the patient was re-examined $1,2,4,8$, and 12 weeks later. At each visit the patient was examined for urethral discharge and a two-glass specimen of urine inspected. A microscopic examination of prostatic fluid was made at 1 month and usually again at 2 months after treatment. Serological tests for syphilis were made at the first visit and 3 months later.

All patients were instructed to return to the clinic immediately if symptoms recurred.

Numbers.-The following numbers of men with new infections of gonococcal urethritis were seen:

\begin{tabular}{|c|c|c|c|c|}
\hline Hospital & & 1962 & 1963 & Total \\
\hline $\begin{array}{l}\text { St. Thomas' } \\
\text { University College } \\
\text { St. Bartholomew's }\end{array}$ & $\begin{array}{l}\cdots \\
\cdots \\
\cdots\end{array}$ & $\begin{array}{l}993 \\
922 \\
131\end{array}$ & $\begin{array}{r}1,053 \\
1,023 \\
163\end{array}$ & $\begin{array}{r}2,046 \\
1,945 \\
294\end{array}$ \\
\hline Total & $\ldots$ & 2,046 & 2,239 & 4,285 \\
\hline
\end{tabular}

Some patients were not given the routine treatment outlined above for one reason or another, and the final totals for each method were:

\begin{tabular}{rr|r|r|r}
\hline \multicolumn{2}{c|}{ Treatment } & 1962 & 1963 & Total \\
\hline $\begin{array}{l}\text { Procaine Penicillin } \\
600,000 \text { units }\end{array}$ & $\ldots$ & 1,085 & 1,173 & 2,258 \\
$\begin{array}{r}\text { Streptomycin 1-2 } \\
\text { g. }\end{array}$ &. & 896 & 945 & 1,841 \\
\hline Total.. &. & 1,981 & 2,118 & 4,099 \\
\hline
\end{tabular}




\section{Relapse}

Definition of Relapse.-Patients with gonococcal urethritis have been defined as relapsing if gonococci reappeared within 14 days of treatment, and if further sexual intercourse was denied. Recurrences in all other patients were defined as re-infections. These definitions (advocated by Dallas, 1958) are arbitrary, but some definition is required for a comparative analysis to be made.

\section{Management of Relapse}

(a) At St. Thomas' and St. Bartholomew's Hospitals.-If relapse occurred after a single injection of 600,000 units procaine penicillin, the diagnosis was confirmed by culture, the oxidase test, and fermentation reactions, and a single intramuscular injection of 2.5 mega-units "Triplopen" (crystalline penicillin 1 mega-unit, procaine penicillin 0.5 megaunit, and benzathene penicillin 1 mega-unit) was given. If relapse occurred again, intramuscular injections of 5 mega-units crystalline (benzyl) penicillin twice daily were given for 3 days.

(b) At University College Hospital.-If relapse occurred after streptomycin, a single injection of 600,000 units procaine penicillin was given. If relapse occurred again, 2.5 mega-units "Triplopen" were given, and if this failed the patient was treated with one of the tetracycline antibiotics.

Incidence of Relapse.-In estimating the number of relapses, patients who attended for treatment only and did not return for follow-up have been counted as successes. Most patients will return to the same clinic if symptoms recur soon after treatment, but seamen and the like may be unable to do so. The figures for the incidence of relapse, therefore, underestimate the true state of affairs.

The incidence of relapse with the two drugs is shown in Table I. A relapse rate of 11.4 per cent. was obtained with 600,000 units procaine penicillin and of 19.1 per cent. using 1-2 g. streptomycin.

TABLE I

INCIDENCE OF RELAPSE IN 1962 and 1963

\begin{tabular}{|c|c|c|c|c|c|c|c|c|c|}
\hline \multirow{3}{*}{ Dosage } & \multicolumn{3}{|c|}{1962} & \multicolumn{3}{|c|}{1963} & \multicolumn{3}{|c|}{ Total } \\
\hline & \multirow{2}{*}{$\begin{array}{c}\text { No. } \\
\text { Treat- } \\
\text { ed }\end{array}$} & \multicolumn{2}{|c|}{ Relapses } & \multirow{2}{*}{$\begin{array}{l}\text { No. } \\
\text { Treat- } \\
\text { ed }\end{array}$} & \multicolumn{2}{|c|}{ Relapses } & \multirow{2}{*}{$\begin{array}{c}\text { No. } \\
\text { Treat- } \\
\text { ed }\end{array}$} & \multicolumn{2}{|c|}{ Relapses } \\
\hline & & No. & \begin{tabular}{|c} 
Per \\
cent.
\end{tabular} & & No. & $\begin{array}{c}\text { Per } \\
\text { cent. }\end{array}$ & & No. & $\begin{array}{c}\text { Per } \\
\text { cent }\end{array}$ \\
\hline $\begin{array}{l}\text { Procaine } \\
\text { Penicillin } \\
(600,000 \\
\text { units) }\end{array}$ & 1,085 & 110 & $10 \cdot 1$ & 1,173 & 147 & $12 \cdot 5$ & 2,258 & 257 & $11 \cdot 4$ \\
\hline $\begin{array}{l}\text { Strepto- } \\
\text { mycin } \\
(1-2 \text { g.) }\end{array}$ & 896 & 154 & $17 \cdot 2$ & 945 & 198 & 21 & 1,841 & 352 & $19 \cdot 1$ \\
\hline
\end{tabular}

Results with "Triplopen".-Of 257 initial relapses after 600,000 units procaine penicillin, all except three were re-treated with a single injection of $2 \cdot 5$ mega-units "Triplopen"; 33 of these (13 per cent.) relapsed again after "Triplopen". This gives a cumulative cure rate with "Triplopen" of 98.5 per cent.

Results with Crystalline Penicillin.-All 33 patients who relapsed after "Triplopen" were retreated with 5 mega-units crystalline penicillin twice daily for 3 days and all were cured, giving a cumulative curerate of 100 per cent.

Five patients did not complete the injections. Two missed the final injection and two missed the last two injections, but all four were cured. One patient defaulted after the second injection, relapsed 2 days later, was re-treated, and was cured after six injections of crystalline penicillin.

Discussion.-These results are in general agreement with other recently published reports.

Streptomycin 1-2 g. gave the least satisfactory results in the treatment of men with gonococcal urethritis. In theory the large dose of crystalline penicillin is ideal, but it does necessitate attendance twice daily for 3 days for painful injections, and it is noteworthy that, of the few patients who were so treated, 13 per cent. defaulted before treatment was complete. "Triplopen" ( 2.5 mega-units) is a "oneshot" method with a very high cure-rate, but has the theoretical disadvantage that the long low level of penicillinaemia, resulting from the incorporation of benzathene penicillin, might be responsible for inducing penicillin-insensitive organisms (Curtis and Wilkinson, 1958) and the practical disadvantage that it is painful. Procaine penicillin $(600,000$ units), also a "one-shot" method, is relatively painless but has a lower cure-rate. The results show that, whatever method is used in the treatment of gonorrhoea, careful follow-up is essential.

\section{Combined Streptomycin and Sulphonamide}

At St. Thomas' Hospital during 1962-3, men with urethritis who attended when the Venereal Disease Clinic was closed were seen in the Casualty Department; they had a urethral smear taken (but not examined) and were given a single injection of $1 \mathrm{~g}$. streptomycin and $0.5 \mathrm{~g}$. sulphamethoxypyridazine daily for 5 days. The patients, with their smears, were seen in the clinic on the next day on which it was open.

Altogether 85 men with gonococcal urethritis were treated with this regime. Twenty of them (23.5 per cent.) relapsed after treatment. This failure rate is similar to that for men with gonococcal urethritis 
treated with streptomycin alone at University College Hospital (19.1 per cent.- see Table I).

Discussion.-These findings, contrary to those of Durel, Roiron, and Delouche (1962) in France, indicate that streptomycin and a sulphonamide combined are no more effective than streptomycin alone in the treatment of gonorrhoea. The clinical results do not support the suggestion that gonococci are regaining their sensitivity to the sulphonamides.

\section{Variation in the Incidence of Relapse}

The proportion of men with gonococcal urethritis who relapsed after treatment varied in different quarters of the year. Figures for St. Thomas' and for University College Hospital are given in Table II, the incidence being shown as a percentage of the total number of all new male cases of gonorrhoea treated in each quarter. The incidence varied between 7.5 and 14.2 per cent. for procaine penicillin and between 10.3 and 19.8 per cent. for streptomycin.

TABLE II

QUARTERLY INCIDENCE OF RELAPSE

\begin{tabular}{|c|c|c|c|c|c|}
\hline \multirow{2}{*}{ Year } & \multirow{2}{*}{ Quarter } & \multicolumn{2}{|c|}{$\begin{array}{l}\text { St. Thomas' Hospital } \\
\text { (Procaine Penicillin) }\end{array}$} & \multicolumn{2}{|c|}{$\begin{array}{c}\text { University College Hospital } \\
\text { (Streptomycin) }\end{array}$} \\
\hline & & $\begin{array}{l}\text { No. of } \\
\text { Relapses }\end{array}$ & $\begin{array}{l}\text { Incidence } \\
\text { (per cent.) }\end{array}$ & $\begin{array}{c}\text { No. of } \\
\text { Relapses }\end{array}$ & $\begin{array}{l}\text { Incidence } \\
\text { (per cent.) }\end{array}$ \\
\hline 1962 & $\begin{array}{l}\text { 1st } \\
\text { 2nd } \\
\text { 3rd } \\
4 \text { th }\end{array}$ & $\begin{array}{l}14 \\
29 \\
25 \\
26\end{array}$ & $\begin{array}{r}7 \cdot 5 \\
13 \cdot 4 \\
8 \cdot 7 \\
10 \cdot 5\end{array}$ & $\begin{array}{l}23 \\
31 \\
49 \\
51\end{array}$ & $\begin{array}{l}10 \cdot 3 \\
12 \cdot 2 \\
17 \cdot 5 \\
18 \cdot 2\end{array}$ \\
\hline 1963 & $\begin{array}{l}\text { 1st } \\
\text { 2nd } \\
\text { 3rd } \\
4 \text { th }\end{array}$ & $\begin{array}{l}25 \\
37 \\
34 \\
24\end{array}$ & $\begin{array}{r}11 \cdot 5 \\
14 \cdot 2 \\
9 \cdot 6 \\
9 \cdot 0\end{array}$ & $\begin{array}{l}43 \\
42 \\
61 \\
52\end{array}$ & $\begin{array}{l}17 \cdot 1 \\
17 \cdot 2 \\
19 \cdot 8 \\
19 \cdot 5\end{array}$ \\
\hline
\end{tabular}

The percentage monthly incidence of relapses at St. Thomas' Hospital shows even more marked variations (Fig. 1), between 4.2 and 13.8 per cent. in 1962 and between 3.4 and $16 \cdot 1$ per cent. in 1963 . Fig. 1 also shows that there is no consistent seasonal variation in the incidence of relapse after treatment with procaine penicillin.

Discussion.-This quarterly and monthly variation in the incidence of relapse is consistent with the impression in the clinics that relapses tend to occur in "runs". During 1963 a check was made to see if these "runs" coincided with the introduction of new batches of antibiotics. No such correlation could be found. There is, therefore, no evidence that these "runs" of failures are due to the use of an antibiotic preparation of diminished potency.

These wide variations at different times in the proportion of patients not cured, both with procaine penicillin and streptomycin, are consistent with laboratory reports of variation in the incidence of antibiotic insensitive strains of gonococci at different times (Curtis and Wilkinson, 1958; M.R.C. Interim Report, 1961).

\section{Subsequent Re-infection after Relapse}

In 21 men in whom gonococcal urethritis relapsed after 600,000 units procaine penicillin in 1962, there were 35 subsequent re-infections, again treated with the same dose of procaine penicillin, by the end of 1963. Patients who admitted re-infection from the same untreated sex contact have been omitted. Of the 35 re-infections, five $(14 \cdot 2$ per cent.) relapsed.

Similarly, eighteen patients who relapsed after 1-2 g. streptomycin in 1962 had 28 subsequent

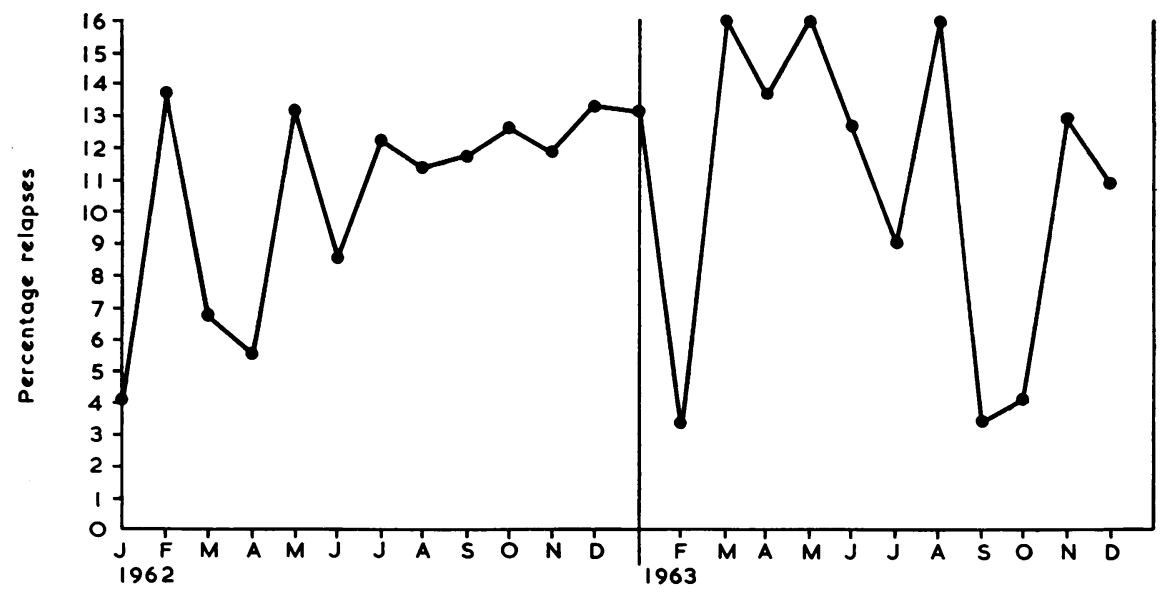

FIG. 1.-Monthly incidence of relapse (1962-3)-procaine penicillin 600,000 units. 
reinfections during 1963, also treated with streptomycin. Again patients who admitted re-infection from the same untreated source have been omitted. Of the 28 re-infections, six ( $21 \cdot 3$ per cent.) relapsed.

Discussion.-The incidence of relapses in subsequent re-infections $(14.2$ per cent. for procaine penicillin and $21 \cdot 3$ per cent. for streptomycin) is similar to that for the whole series $(11.4$ per cent. for procaine penicillin and $19 \cdot 1$ per cent. for streptomycin). Response to treatment in previous infections, therefore, appears irrelevant to the occurrence of relapse in subsequent re-infections treated with the same antibiotic, provided re-infection from the same untreated source has not occurred.

Thayer, Field, Perry, Martin, and Garson (1961) reported that some patients have an abnormally low serum level after a given dose of penicillin. It has been suggested that some therapeutic failures in gonorrhoea may be due to "host factors", such as abnormal absorption, metabolism, or excretion, resulting in low tissue levels of the antibiotic used (Hirsch, Finland, and Willcox, 1960; Guthe, 1961; Willcox, 1962). Such "host factors" would cause relapse both with the initial infection and with subsequent re-infections treated by the same drug and dosage. No evidence has, therefore, been found in this series that "host factors" are a common cause of relapse.

\section{Other Factors and Relapse}

The men in whom gonococcal urethritis relapsed after 600,000 units procaine penicillin have been

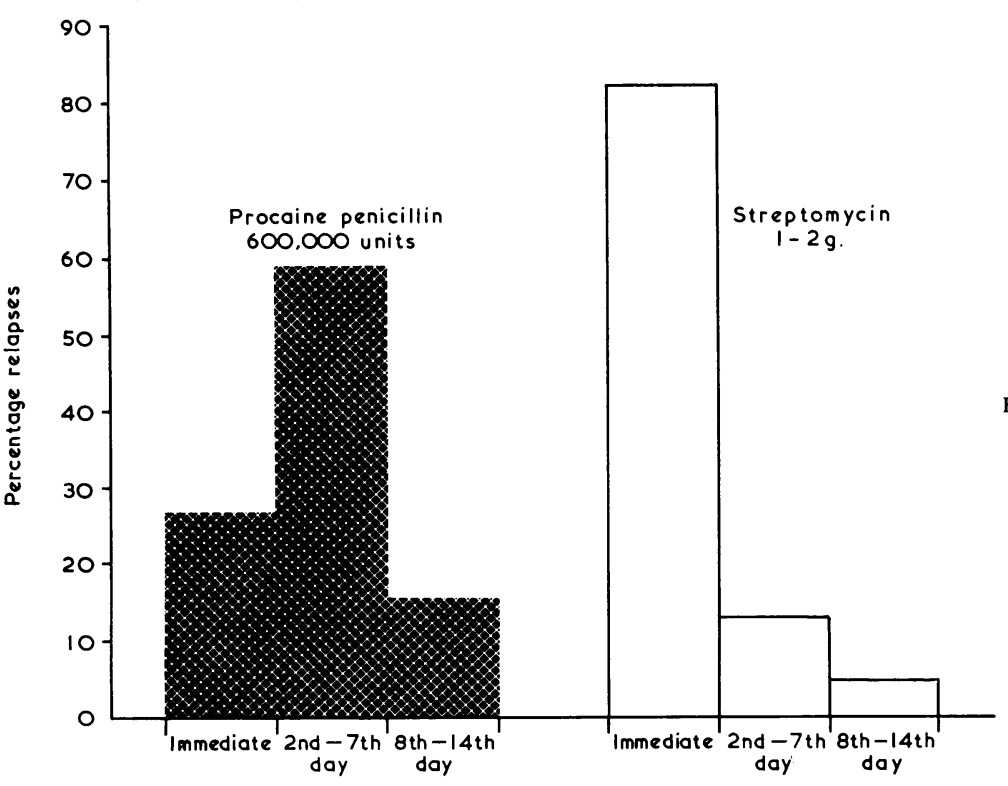

compared with a control group consisting of the first 100 men presenting with new infections of gonococcal urethritis in 1963 at St. Thomas' Hospital. A similar comparison was made between men who relapsed after streptomycin and the first 100 men with new infections in 1963 at University College Hospital. The results of this comparison showed that:

(1) Patients in any particular age group showed no increased liability to relapse.

(2) No particular racial group showed any increased liability to relapse after treatment.

(3) Patients who had previously had gonococcal urethritis treated with penicillin or streptomycin showed no particular liability to relapse with the same antibiotic in a subsequent infection. Similar findings with penicillin have been previously reported (Gjessing, 1959).

\section{Timing of Relapse}

In men with gonococcal urethritis, relapse may occur in one of two ways:

(a) Immediate Type.--Symptoms are still present and the urethral discharge still contains gonococci the day after treatment;

(b) Delayed Type.-After a symptom-free and (apparently) gonococci-free interval, symptoms recur and gonococci are again found (Curtis and Wilkinson, 1958; Alergant, 1958).

Table III shows the interval between treatment with procaine penicillin or streptomycin and the reappearance of gonococci. Fig. 2 shows the same results.

FIG. 2.-Timing of relapses with procaine penicillin and with streptomycin. 
TABLE III

TIMING OF RELAPSE AFTER TREATMENT

\begin{tabular}{|c|c|c|c|c|c|c|}
\hline \multirow{2}{*}{$\begin{array}{l}\text { Treatment } \\
\text { Relapses }\end{array}$} & \multirow[t]{2}{*}{$\cdots$} & \multirow[t]{2}{*}{$\cdots$} & \multicolumn{2}{|c|}{$\begin{array}{l}\text { Procaine } \\
\text { Penicillin }\end{array}$} & \multicolumn{2}{|c|}{ Streptomycin } \\
\hline & & & Number & $\begin{array}{c}\text { Per } \\
\text { cent. }\end{array}$ & Number & $\begin{array}{l}\text { Per } \\
\text { cent. }\end{array}$ \\
\hline $\begin{array}{l}\text { Post-Treatment } \\
\text { Day }\end{array}$ & & $\begin{array}{l}1 \mathrm{st} \\
2 \mathrm{nd} \text { to } 7 \mathrm{th} \\
8 \text { th to } 14 \mathrm{th}\end{array}$ & $\begin{array}{r}68 \\
153 \\
36\end{array}$ & $\begin{array}{l}26 \\
59 \\
15\end{array}$ & $\begin{array}{r}288 \\
45 \\
19\end{array}$ & $\begin{array}{r}82 \\
13 \\
5\end{array}$ \\
\hline Total $\ldots$ & $\cdots$ & $\cdots$ & 257 & 100 & 352 & 100 \\
\hline
\end{tabular}

Differences were observed between the timing of relapses with penicillin and streptomycin. After streptomycin a high proportion ( 82 per cent.) of the relapses were "immediate" as compared with only 26 per cent. after procaine penicillin. With the latter drug, the largest number of relapses ( 59 per cent.) occurred between the 2nd and 7th day after treatment, whereas with streptomycin only 13 per cent. occurred during this period. Relapse occurred in the second week after treatment in 15 per cent. of those who had procaine penicillin, but in only 5 per cent. of those who had streptomycin.

Discussion.-These clinical findings are consistent with the study of the streptomycin sensitivity of gonococci in vitro by Reyn (1961), which showed that most strains were either fully sensitive or completely resistant. Most patients not cured by streptomycin showed the "immediate" type of failure, suggesting that the gonococcus was completely resistant to the antibiotic. With penicillin reduced sensitivity rather than complete resistance is seen (King, 1960), and most patients who fail show the "delayed" type of relapse.

Different definitions of "relapse" and of "reinfection" will result in different failure rates with the two drugs in question. If relapse is defined as the persistence of gonococci the day after treatment (as suggested by Knight, 1958), then the failure rates in this study would have been 2.9 per cent. for procaine penicillin and 16.7 per cent. for streptomycin instead of 11.4 and 19.1 per cent. respectively with the definitions used. Similarly, as 15 per cent. of relapses after procaine penicillin occurred in the second week after treatment and only 5 per cent. with streptomycin, the definition of relapse advocated by the M.R.C. Interim Report (1961) of up to one week after treatment would give a bias in favour of penicillin.

\section{Timing of Relapse and Sensitivity of Gonococci to Penicillin}

The sensitivity to penicillin of the gonococci isolated was estimated in a few patients who relapsed after 600,000 units procaine penicillin. No correla- tion was found between the degree of penicillin sensitivity of the infecting gonococcus and the interval between treatment and relapse. Table IV shows that some of the more sensitive strains produced relapses of the "immediate" type, and some of the less sensitive strains produced relapses of the "delayed" type.

TABLE IV

TIMING OF RELAPSE AFTER TREATMENT WITH PENICILLIN, AND PENICILLIN SENSITIVITY OF GONOCOCCI

\begin{tabular}{l|c|c|c|c|c|c|c|c}
\hline $\begin{array}{c}\text { Penicillin } \\
\text { Sensitivity } \\
\text { (u./ml.) }\end{array}$ & \multicolumn{3}{|c|}{ Number of Patients Relapsing at given Time (days) } \\
\cline { 2 - 8 } & Immediate & 2 & 3 & 4 & 5 & 6 & 7 & $8-14$ \\
\hline $\mathbf{0 . 0 3}$ & - & - & 1 & - & - & - & - & - \\
$\mathbf{0 . 0 6}$ & 2 & - & 1 & 1 & - & - & 1 & - \\
$\mathbf{0 . 1 2 5}$ & 3 & - & 1 & 1 & 1 & 1 & 1 & - \\
$\mathbf{0 . 2 5}$ & 1 & 1 & - & - & - & 1 & 1 & 1 \\
$\mathbf{0 . 5}$ & 2 & - & - & 1 & 1 & - & - & - \\
\hline
\end{tabular}

Discussion.-The lack of correlation between the sensitivity to penicillin of the causative gonococci and the interval between treatment and relapse is difficult to explain.

Reyn, Korner, and Bentzon (1958) suggested that there may be clones of different sensitivity within a single strain. Were this so, sensitivity in vitro would be only a measure of the sensitivity of the least sensitive clone. Standard dosage of penicillin might eradicate all but a few organisms of low sensitivity, and the interval between treatment and relapse would depend on the time taken for the surviving organisms to multiply sufficiently for a clinical and bacteriological relapse to develop. If this hypothesis is correct, the rapidity with which relapse becomes apparent would depend not so much on the sensitivity of the gonococcus in vitro as on the number of organisms that survived the initial treatment. If most of the organisms survived, relapse would be "immediate", whereas if only a few survived relapse would be "delayed".

Some support for this hypothesis can be obtained from the common clinical observation in gonococcal urethritis with the "immediate" type of relapse, that many patients report marked symptomatic improvement and diminished urethral discharge, though gonococci are still present. In such cases, presumably, large numbers of organisms are killed with consequent symptomatic improvement, but sufficient remain to be detected in the stained smear.

\section{Antibiotic Sensitivity of Organisms isolated from Patients who Relapsed}

(a) Penicillin Sensitivity.-Sensitivity determinations were carried out on gonococci isolated from 23 of the men in whom gonococcal urethritis relapsed after treatment with 600,000 units procaine penicillin 
(Table V); seventeen (74 per cent.) of the gonococci isolated after relapse showed reduced sensitivity to penicillin.

TABLE V

PENICILLIN SENSITIVITY OF GONOCOCCI IN 23 RELAPSING CASES

\begin{tabular}{c|c}
\hline $\begin{array}{c}\text { Penicillin Sensitivity } \\
\text { (u./ml.) }\end{array}$ & $\begin{array}{c}\text { No. of } \\
\text { Cases } \\
\text { Relapsing }\end{array}$ \\
\hline 0.03 & 1 \\
0.06 & 5 \\
0.125 & 8 \\
0.25 & 5 \\
0.5 & 4 \\
\hline
\end{tabular}

The organisms isolated from a further 22 similar patients were tested for penicillin sensitivity by a disk method; seventeen (78 per cent.) of them showed "reduced sensitivity".

Discussion.-These results are consistent with the large number of published reports that relapse after treatment with penicillin is associated with the presence of gonococci relatively insensitive to penicillin in vitro. Surprisingly, no strain with a sensitivity less than 0.5 units $/ \mathrm{ml}$. has been found. This again is in keeping with current reports, the least sensitivity so far reported being 2 units $/ \mathrm{ml}$. Miller and Bohnhoff (1945), by growing gonococci in culture media containing increasing concentrations of penicillin, produced a strain of gonococcus that would withstand a penicillin concentration of 21 units/ $\mathrm{ml}$. in vitro. It is difficult to explain why conditions in vivo have not as yet produced a strain with a reduced sensitivity approaching that attained in vitro.

(b) Streptomycin Sensitivity.-At St. Thomas' Hospital, from April, 1962, until the end of 1963, men in whom gonococcal urethritis relapsed after 600,000 units procaine penicillin have had the streptomycin sensitivity of their gonococci estimated, using a disk containing $10 \mu \mathrm{g}$. streptomycin. Controls were obtained by estimating the streptomycin sensitivity, by the same method, of the strain isolated from the first new male patient with gonococcal urethritis, each morning from November, 1962, to February, 1963. Table VI shows the results obtained; only 18 per cent. of the strains isolated

TABLE VI

STREPTOMYCIN SENSITIVITY OF GONOCOCCI FROM PATIENTS RELAPSING AFTER PENICILLIN AND FROM CONTROLS

\begin{tabular}{c|c|c|c|c}
\hline \multirow{2}{*}{ Gonococci } & \multicolumn{2}{|c|}{ Relapses } & \multicolumn{2}{c}{ Controls } \\
\cline { 2 - 5 } & No. & Per cent. & No. & Per cent. \\
\hline Streptomycin Sensitive & 12 & 11 & 41 & 82 \\
Streptomycin Resistant & 96 & 89 & 9 & 18 \\
\hline
\end{tabular}

from the controls were streptomycin resistant, whereas 89 per cent. of the strains from patients who relapsed after 600,000 units procaine penicillin were streptomycin resistant.

The probability that patients infected with streptomycin-resistant strains of gonccocci will not be cured with 600,000 units procaine penicillin is also shown by the response to treatment of the control patients. All 41 controls from whom strains sensitive to streptomycin were isolated were cured by 600,000 units procaine penicillin, but six (67 per cent.) of the nine patients with strains resistant to streptomycin were not cured by this dose of penicillin; one went abroad the same day and remained untraced, and two patients were cured.

During 1963, when examining the female sex contacts of men with gonococcal urethritis who relapsed after procaine penicillin and from whom streptomycin-resistant gonococci had been isolated, the streptomycin sensitivity of the gonococcus isolated from the women was estimated also. Only nine such "pairs" were seen, but in all of them strains resistant to streptomycin were isolated from both man and woman.

\section{Results of Penicillin Therapy after Relapse with Streptomycin}

The high incidence of streptomycin resistance in vitro amongst gonococci from patients who relapsed after 600,000 units procaine penicillin suggested that many patients not cured with streptomycin would also fail with 600,000 units procaine penicillin.

Of 341 men with gonococcal urethritis at University College Hospital who relapsed after 1-2 g. streptomycin and were then re-treated with 600,000 units procaine penicillin, $132(38.7$ per cent.) were not cured. This failure rate is more than three times greater than that with the same dose of procaine penicillin in unselected patients at St. Thomas' and St. Bartholomew's Hospitals (11.4 per cent.) as is shown in Table VII.

TABLE VII

FAILURE RATE WITH PENICILLIN IN PATIENTS NOT CURED WITH STREPTOMYCIN

\begin{tabular}{l|c|c|c}
\hline $\begin{array}{c}\text { Procaine Penicillin } \\
(600,000 \text { units })\end{array}$ & $\begin{array}{c}\text { Number } \\
\text { Treated }\end{array}$ & \multicolumn{2}{|c}{ Relapses } \\
\cline { 1 - 3 } & 2,258 & No. & Per cent. \\
\hline Unselected Patients & 341 & $11 \cdot 4$ \\
\hline $\begin{array}{l}\text { After Failure with } \\
\text { Streptomycin }\end{array}$ & 132 & $38 \cdot 7$ \\
\hline
\end{tabular}

Discussion

It has been shown that:

(a) Gonococci isolated from patients with gonococcal urethritis who did not respond to procaine 
penicillin usually showed streptomycin resistance in vitro.

(b) Patients with gonococcal urethritis who have failed to respond to streptomycin have a much greater failure rate than unselected patients when subsequently treated with 600,000 units procaine penicillin.

These results are a clinical confirmation of the observation in vitro that streptomycin-resistant gonococci tend to have reduced penicillin sensitivity and vice versa (Reyn, 1961; Gjessing and Ödegaard, 1962b; Schmidt and Larsen, 1962).

Probably this cross-resistance between penicillin and streptomycin is of recent origin. Reyn and others (1958) in Denmark found cross-resistance in gonococci collected in 1957 but not in those from 1944, while Curtis and Wilkinson (1958) in London found no evidence of cross-resistance in 81 strains of gonococci. Miller and Bohnhoff (1946) showed that inducing penicillin insensitivity in gonococci in vitro did not alter their streptomycin sensitivity and vice versa. Cross-resistance between penicillin and streptomycin must, therefore, be acquired separately for each drug.

The usually accepted explanation for this crossresistance is that streptomycin has been used as the drug of choice in gonorrhoea when penicillin fails. It is true that streptomycin is a drug to which gonococci easily and quickly develop resistance, but streptomycin has been little used in the treatment of gonorrhoea in England.

Results of Therapy in the Female Sex Contacts of Men who relapsed after Treatment (Table VIII)

If relapse occurs in a man with gonococcal urethritis because the gonococcus has diminished sensitivity to the antibiotic used, treatment of his female sex contact with the same antibiotic should also fail.

TABLE VIII

RESULTS OF TREATMENT IN FEMALE CONTACTS OF MEN WHO RELAPSED

\begin{tabular}{l|c|c|c|c|c|c}
\hline \multirow{2}{*}{ Treatment } & \multicolumn{2}{|c|}{ Female Contacts } & \multicolumn{2}{|c}{ Unselected Women } \\
\cline { 2 - 6 } & Total & Relapses & & \multicolumn{2}{|c|}{ Relapses } \\
\cline { 3 - 6 } & No. & $\begin{array}{c}\text { Per } \\
\text { cent. }\end{array}$ & Total & No. & $\begin{array}{c}\text { Per } \\
\text { cent. }\end{array}$ \\
\hline $\begin{array}{l}\text { Procaine Penicillin } \\
(600,000 \text { units) }\end{array}$ & 55 & 47 & 86 & 566 & 52 & $9 \cdot 2$ \\
\hline $\begin{array}{l}\text { Streptomycin } \\
\text { (5 g.) }\end{array}$ & 34 & 31 & 91 & 408 & 93 & $22 \cdot 8$ \\
\hline
\end{tabular}

The records of all the known female sex contacts of men who relapsed after standard therapy have been examined. The detection of relapse in women is more difficult than in men, since isolation of the gonococci in women is often difficult (Rees, 1952). It has not, therefore, been considered advisable to limit "relapse" in women to those in whom gonococci reappeared within 2 weeks of initial treatment (as has been done in men). Surveillance of women after treatment of uncomplicated gonorrhoea at each hospital has been carried out by the examination of urethral and cervical smears and cultures at intervals of one day, 1 and 2 weeks, and 1, 2, and 3 months after treatment.

Penicillin.-55 female sex contacts of men in whom gonococcal urethritis relapsed after 600,000 units procaine penicillin were found to have uncomplicated gonorrhoea, and were treated with the same dose of procaine penicillin. In 47 of them, gonococci were again found in the post-treatment period, giving a failure rate of 86 per cent. For comparison, among 566 unselected women treated for uncomplicated gonorrhoea with 600,000 units procaine penicillin at St. Thomas' Hospital during the same period, the failure rate was only 9.2 per cent.

Similarly, during 1962-3, 63 women with uncomplicated gonorrhoea were not cured after 600,000 units of procaine penicillin; 45 male sex contacts of these women were found to have gonococcal urethritis and were treated with 600,000 units procaine penicillin, and 38 of them ( 84 per cent.) relapsed after this treatment, compared with 11.4 per cent. of unselected male cases of gonorrhoea. In two instances one woman had two male sex contacts, and in both cases both men relapsed after treatment.

Streptomycin.-34 female sex contacts of men with gonococcal urethritis who relapsed after 1-2 g. streptomycin were found to have uncomplicated gonorrhoea and were treated with $1 \mathrm{~g}$. streptomycin daily for 5 days. In 31 of them treatment failed, giving a failure rate of 91 per cent. For comparison, among 408 unselected women treated for uncomplicated gonorrhoea with the same dose of streptomycin during the same period, the failure rate was only $22 \cdot 8$ per cent.

Discussion.-In 84 to 91 per cent. of patients with heterosexually-transmitted gonorrhoea, if one partner relapsed after either procaine penicillin or streptomycin, the other partner also failed with the same drug and dosage. This clinical finding is in keeping with laboratory reports that strains of gonococci isolated from male and female sex partners show similar antibiotic sensitivity patterns (Curtis and Wilkinson, 1958; Craddock-Watson and others, 1958; Gjessing and Ödegaard, 1962a; Schmidt and Larsen, 1962). 
The clinical implications of this finding are:

(a) If a patient has already failed with one drug, the sex partner should not be treated with the same drug and dosage.

(b) If both sex partners have been given the same treatment, and one partner subsequently fails, surveillance of the second partner should be intensified, in the knowledge that relapse is highly likely.

There would be theoretical advantages in indicating on the contact slip given to patients treated for gonorrhoea, whether relapse had occurred with any drug, or drugs. In this way the Receiving Clinic would be alerted to the likelihood of failure. There are, however, practical difficulties to this proposal, since contact slips are usually issued before the response to treatment is known.

\section{Results of Therapy in Male Homosexual Contacts}

Penicillin.-Of 83 men with gonococcal proctitis treated with 600,000 units procaine penicillin, seventeen $(20.5$ per cent.) relapsed. This failure rate is almost twice that for unselected men with gonococcal urethritis at the same hospitals during the same period and using the same treatment $(11.4$ per cent.).

This higher failure rate in gonococcal proctitis might be due to a preponderance of relatively penicillin-insensitive gonococci among homosexuals, in which case a similarly high failure rate would occur among patients with homosexually-acquired gonococcal urethritis.

Of 132 men with gonococcal urethritis treated with 600,000 units procaine penicillin who stated that their infection had been acquired homosexually, thirteen ( 9.9 per cent.) relapsed after treatment. This failure rate is similar to that for all men with gonococcal urethritis treated with procaine penicillin. It is less than half that in gonococcal proctitis (20.5 per cent.).

25 "pairs" of male patients with homosexually transmitted gonorrhoea were treated with 600,000 units procaine penicillin. In eighteen "pairs" both the active partner with gonococcal urethritis and his passive partner with gonococcal proctitis were cured ( 72 per cent.). In six "pairs" ( 24 per cent.), the active partner with gonococcal urethritis responded to this dose, while his passive partner with gonococcal proctitis did not respond. One man with gonococcal proctitis had two active male sex contacts with gonococcal urethritis, both of whom were cured with 600,000 units procaine penicillin, whereas he was not cured.

In one case, the active partner did not respond to procaine penicillin, while his passive partner responded. However, proctitis was still present in the passive partner one week later, though no gonococci were isolated, and streptomycin and a sulphonamide drug were then given. Possibly further tests would have isolated gonococci again, had this other treatment not been given.

Streptomycin.-Of 52 men with gonococcal proctitis treated with $1-2 \mathrm{~g}$. streptomycin, twelve ( 23 per cent.) relapsed, and of 59 men with homosexuallyacquired gonococcal urethritis, fifteen ( 25 per cent.) relapsed. The failure rates using streptomycin in gonococcal proctitis ( 23 per cent.) and in homosexually-acquired gonococcal urethritis ( 25 per cent.) are therefore similar to that with streptomycin in unselected men with gonococcal urethritis $(19 \cdot 1$ per cent.).

In fourteen "pairs" both active and passive partners in homosexually-transmitted gonorrhoea were treated with $1-2 \mathrm{~g}$. streptomycin. In nine of these "pairs" both partners were cured and in the other five both relapsed. In no instance did the active partner respond while his passive partner failed with streptomycin, as happened with penicillin (Tables IX and X).

TABLE IX

FAILURE RATE IN MEN WITH

HOMOSEXUALLY-TRANSMITTED GONORRHOEA

\begin{tabular}{|c|c|c|c|c|c|c|}
\hline \multirow{3}{*}{ Treatment } & \multicolumn{3}{|c|}{ Proctitis } & \multicolumn{3}{|c|}{ Urethritis } \\
\hline & \multirow[b]{2}{*}{ Total } & \multicolumn{2}{|c|}{ Failures } & \multirow[b]{2}{*}{ Total } & \multicolumn{2}{|c|}{ Failures } \\
\hline & & No. & $\begin{array}{c}\text { Per } \\
\text { cent. }\end{array}$ & & No. & $\begin{array}{c}\text { Per } \\
\text { cent. }\end{array}$ \\
\hline $\begin{array}{l}\text { Procaine Penicillin } \\
\text { ( } 600,000 \text { units) }\end{array}$ & 83 & 17 & $20 \cdot 5$ & 132 & 13 & $9 \cdot 9$ \\
\hline Streptomycin (1-2 g.) & 52 & 12 & 23 & 59 & 15 & $25 \cdot 4$ \\
\hline
\end{tabular}

TABLE $\mathbf{X}$

RESULTS OF TREATMENT OF ACTIVE AND PASSIVE PARTNERS IN

HOMOSEXUALLY-TRANSMITTED GONORRHOEA

\begin{tabular}{l|c|c|c|c|c}
\hline \multicolumn{1}{|c|}{ Treatment } & $\begin{array}{c}\text { Total } \\
\text { Homo- } \\
\text { sexual } \\
\text { "Pairs" }\end{array}$ & $\begin{array}{c}\text { Both } \\
\text { Cured }\end{array}$ & $\begin{array}{c}\text { Both } \\
\text { Failed }\end{array}$ & $\begin{array}{c}\text { Urethritis } \\
\text { Cured } \\
\text { Proctitis } \\
\text { Failed }\end{array}$ & $\begin{array}{c}\text { Proctitis } \\
\text { Cured } \\
\text { Urethritis } \\
\text { Failed }\end{array}$ \\
\hline $\begin{array}{l}\text { Procaine } \\
\text { Penicillin } \\
(600,000 \text { units })\end{array}$ & 25 & 18 & - & 6 & $? 1$ \\
$\begin{array}{l}\text { Streptomycin } \\
(1-2 \text { g.) }\end{array}$ & 14 & 9 & 5 & - & - \\
\hline
\end{tabular}

Discussion.-The treatment of gonococcal proctitis with streptomycin is about as successful as the streptomycin treatment of gonococcal urethritis, whether homosexually-acquired or not. Using procaine penicillin, however, the failure rate in gonococcal proctitis is double that in gonococcal urethritis, 
however acquired. If the active partner with gonococcal urethritis is cured with streptomycin the passive partner with gonococcal proctitis will also respond, and if the active partner relapses the passive partner will also relapse. Using procaine penicillin, however, in some "pairs" the passive partner with gonococcal proctitis will fail, while the active partner with gonococcal urethritis will be cured.

Thayer, Field, Magnuson, and Garson (1957) have shown that, in women with gonococcal infection of both cervix and rectum, the organism isolated from each site in the same women had the same penicillin sensitivity. This would indicate that presence in the rectum does not alter the penicillin sensitivity of the gonococcus.

It has been suggested (King and Nicol, 1962) that the presence of penicillinase-producing organisms in the rectum might partially protect the gonococcus against penicillin. The finding of an increased failure rate in gonococcal proctitis treated with procaine penicillin, but of no such increase with streptomycin, would support this hypothesis.

The high failure rate in men with gonococcal proctitis treated with 600,000 units procaine penicillin suggests that either a higher dosage or a different drug should be used in this condition. Presumably the same is true in women with gonorrhoea and rectal involvement. The report by Jensen (1953) does not confirm this view, but Scott and Stone (1966) found a high failure rate in women with gonococcal proctitis treated with 600,000 units procaine penicillin.

\section{Value of Cultures in Women who Relapse}

It is generally accepted that, in the diagnosis of gonorrhoea in women, cultures from urethra and cervix will frequently confirm the diagnosis when stained smears from the same sites reveal no gonococci (Rees, 1952; Wilkinson, 1952). It seemed important to find out if the same was true of women who relapsed after treatment.

The method whereby relapse was diagnosed (by smears only, by cultures only, or by smears and cultures) in the 63 women in whom relapse occurred after treatment with 600,000 units procaine penicillin during 1962-3 was compared with the method by which the initial diagnosis of gonorrhoea was made in one hundred consecutive women with gonorrhoea seen at St. Thomas' Hospital during 1963 (Controls). Relapse among the 63 women occurred on 68 occasions as five of them relapsed with procaine penicillin and also with "Triplopen".

Table XI shows the results of this comparison. Of women who relapsed, gonococci were found in 52 per cent. after treatment by culture only; whereas the initial diagnosis was made by culture only in only 19 per cent. of unselected women with gonorrhoea. The same personnel performed all tests, and the same techniques were used throughout.

TABLE XI

METHOD OF DIAGNOSIS OF RELAPSE AFTER PROCAINE PENICILLIN COMPARED WITH THAT OF INITIAL DIAGNOSIS IN WOMEN

\begin{tabular}{l|c|c|c|c}
\hline \multirow{2}{*}{ Method of Diagnosis } & \multicolumn{2}{|c|}{$\begin{array}{c}\text { Women who } \\
\text { Relapsed }\end{array}$} & \multicolumn{2}{|c}{ Controls } \\
\cline { 2 - 3 } & No. & Per cent. & No. & Per cent. \\
\hline By smear only & 8 & 11 & 19 & 19 \\
By culture only & 35 & 52 & 19 & 19 \\
By smear and culture & 25 & 37 & 62 & 62 \\
\hline
\end{tabular}

Discussion.-Cultures appear to be even more important in the surveillance of gonorrhoea in women than in the initial diagnosis.

This finding is again consistent with the suggestion by Reyn and others (1958) that there may be clones of different antibiotic sensitivity within a single strain. If this is so, the majority of gonococci (highly penicillin sensitive) would be killed by the standard dose of penicillin, but a minority (weakly penicillin sensitive) would survive. Cultures could be positive in the presence of only very few organisms, whereas a larger number would be needed for diagnosis from a stained smear.

It would be interesting to know what proportion of men who showed the "delayed" type of relapse could be diagnosed by urethral culture on the day after treatment.

\section{Penicillin-Probenecid-Penicillinase Combination}

Curtis and Wilkinson (1958) suggested that the ideal penicillin treatment for gonorrhoea would produce a penicillin level in the tissues of $1 \mathrm{unit} / \mathrm{ml}$. for 18-24 hrs and then rapidly fall to zero. Hilton (1959) showed that an initial injection of 1.2 megaunits procaine penicillin in oil with aluminium monostearate (P.A.M.), followed by 0.5 g. probenecid orally 6-hrly for four doses, would maintain a penicillinaemia greater than $1 \mathrm{unit} / \mathrm{ml}$. for $24 \mathrm{hrs}$. This method, however, does not cause a rapid fall to zero of the serum penicillin level at the end of $24 \mathrm{hrs}$, and so does not eliminate the theoretical disadvantages of the "penicillin tail".

Penicillinase is an enzyme which converts penicillin to the inert penicilloic acid. Becker (1956) and Zimmerman (1958) showed that it was extremely effective in eliminating penicillin serum levels.

After animal trials, the following routine was evolved for use in man:

(1) A single injection of 2.4 mega-units procaine penicillin was given intramuscularly. 


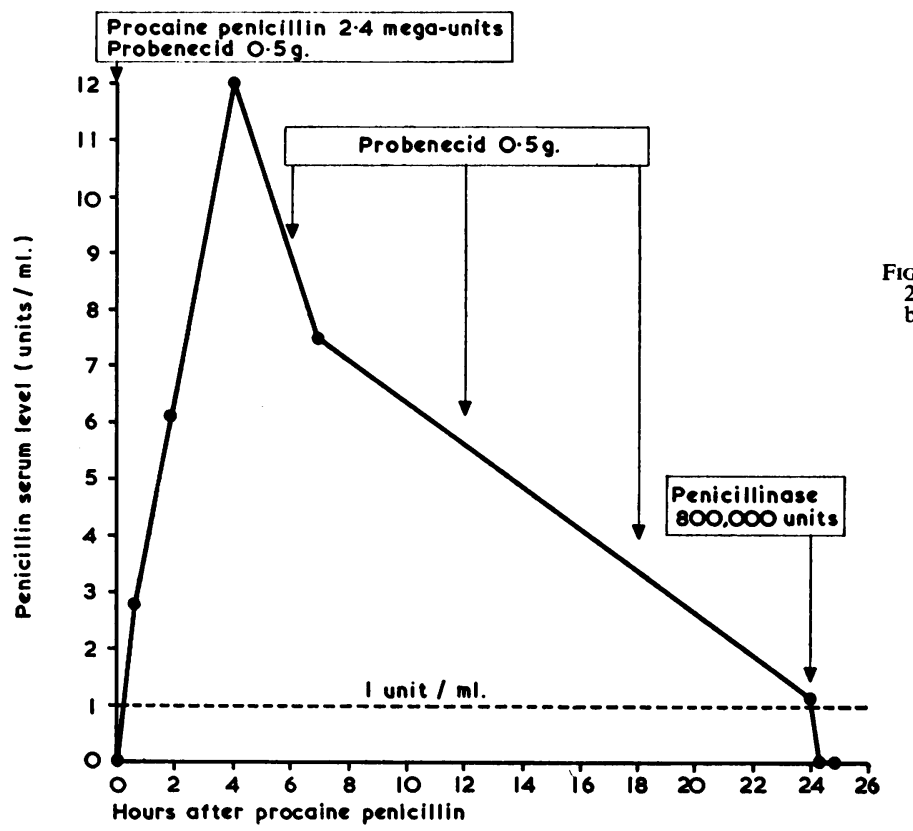

(2) $0.5 \mathrm{~g}$. probenecid was given orally with the penicillin injection, and repeated 6,12 , and $18 \mathrm{hrs}$ later.

(3) $24 \mathrm{hrs}$ after the penicillin injection a single intramuscular injection of penicillinase ("Neutrapen") 800,000 units was given.

Fig. 3 shows in graph form the serum penicillin levels obtained in a male volunteer with this regime. The serum penicillin level had reached $2 \cdot 8$ units $/ \mathrm{ml}$. at $40 \mathrm{~min}$., and after $24 \mathrm{hrs}$ it was still $1 \cdot 2$ units $/ \mathrm{ml}$. 30 and $60 \mathrm{~min}$. after the penicillinase injection, the serum penicillin level was zero.

Discussion.-This regime would have theoretical advantages as a method of treatment in gonorrhoea. It has, however, considerable practical disadvantages. Many out-patients with gonorrhoea would not take their probenecid tablets regularly, and some might not return for the penicillinase injection if they were symptomless the next day. In addition, penicillinase is expensive, and severe anaphylactoid reactions with it have been reported (Becker, 1960).

\section{Summary and Conclusions}

(1) Of 2,258 men with gonococcal urethritis treated by a single intramuscular injection of 600,000 units procaine penicillin, 11.4 per cent. relapsed after treatment. Re-treatment with 2.5 mega-units "Triplopen" resulted in a cumulative cure-rate of 98.5 per cent., while further re-treatment with 5 mega-units crystalline penicillin twice daily for 3 days gave a 100 per cent. cumulative cure-rate.
(2) Of 1,841 men with gonococcal urethritis treated by one or two intramuscular injections of 1 g. streptomycin, $19 \cdot 1$ per cent. relapsed after treatment. A combination of streptomycin and a sulphonamide gave no better results than streptomycin alone.

(3) There were wide variations at different times in the proportion of patients who relapsed, both with procaine penicillin and with streptomycin, but there was no regular seasonal variation. Relapses tended to come in "runs" which were not related to the introduction of a new batch of the antibiotic.

(4) Patients who had previously had gonorrhoea treated with either penicillin or streptomycin (whether this treatment was successful or not) showed no particular liability to fail with the same antibiotic in a subsequent re-infection.

(5) No particular racial group or age group in this study showed any increased liability to relapse after treatment.

(6) Men with gonococcal urethritis who were not cured with streptomycin usually relapsed immediately (i.e. without a symptom-free and apparently gonococcus-free interval), whereas with procaine penicillin the majority of men who relapsed did so between the 2 nd and 7 th day after treatment.

(7) There was no correlation in men with gonococcal urethritis between the interval between treatment and relapse, using procaine penicillin, and the 
penicillin sensitivity in vitro of the gonococcus isolated.

(8) 89 per cent. of the gonococci isolated from men who relapsed after treatment with procaine penicillin were streptomycin resistant. Gonococcal infections with streptomycin-sensitive strains usually responded to treatment with procaine penicillin, while infections with streptomycin-resistant strains frequently failed to do so.

(9) The failure rate with procaine penicillin in men with gonococcal urethritis who had already failed with streptomycin was three times greater than the failure rate with procaine penicillin in unselected patients.

(10) In heterosexually-transmitted gonorrhoea, both with procaine penicillin and with streptomycin, failure of treatment in one patient indicated a high degree of probability (84 to 91 per cent.) that the sex partner would also fail with treatment with the same drug and dosage. If, therefore, one sex partner has already failed to respond to treatment, the same treatment should not be given to the other partner.

(11) In homosexually-transmitted gonorrhoea treated with 1-2 g. streptomycin, the failure rates of proctitis and of urethritis were similar. When 600,000 units procaine penicillin were used, the failure rate in gonococcal proctitis was twice as large as that in homosexually-acquired gonococcal urethritis. In some homosexual "pairs" with gonorrhoea, treatment with 600,000 units procaine penicillin cured the active partner with gonococcal urethritis but failed to cure the passive partner with gonococcal proctitis. Using streptomycin in similar "pairs", either both partners were cured or both relapsed. Gonococcal proctitis should, therefore, be treated either with a larger dose of penicillin or with a different drug.

(12) In more than half of the women with gonorrhoea who were not cured with procaine penicillin, the diagnosis of relapse could be made by culture only. Frequent cultural examination is, therefore, essential in the surveillance of gonorrhoea in the female.

(13) A combination of procaine penicillin and probenecid followed by penicillinase produced a serum penicillin level of over $1 \mathrm{unit} / \mathrm{ml}$. for $24 \mathrm{hrs}$ and then a rapid fall to zero. Such a regime would have theoretical advantages as a treatment for gonorrhoea, but for practical reasons is not recommended.

I wish to thank Dr C. S. Nicol for permission to study the patients at St Thomas' and St. Bartholomew's Hospitals, and Dr E. Gwynne Thomas for permission to study the patients at University College Hospital. I am also indebted to both of them for much help and encouragement. My thanks are also due to all my colleagues -medical, nursing, technical, and secretarial-at all three hospitals, and particularly to Dr John Seale and Mr A. H. Stone. I also wish to thank Dr A. E. Wilkinson for the quantitative penicillin sensitivity estimations carried out at the V.D. Reference Laboratory.

\section{REFERENCES}

Abraham, E. P., Chain, E., Fletcher, C. M., Gardner, A. D., Heatley, N. G., Jennings, M. A., and Florey, H. W. (1941). Lancet, $2,177$.

Alergant, C. D. (1958), Brit. J. vener. Dis., 34, 36.

Becker, R. M. (1956), New Engl.J. Med., 254, 952.

Becker, R. M. (1960). Practitioner, 184, 447.

Cradock-Watson, J. E., Shooter, R. A., and Nicol, C. S. (1958). Brit. med. J. 1, 1091.

Curtis, F. R., and Wilkinson, A. E. (1958), Brit. J. vener. Dis., 34, 70.

Dallas, N. L. (1958), Ibid., 34, 194.

Durel, P., Roiron, V., and Delouche, L. (1962). Bull. Wid Hlth Org., 24, 343.

Gjessing, H. C. (1959). Brit. J. vener. Dis., 35, 256

$\longrightarrow$ and Ödegaard, K. (1962a), Ibid., 38, 26. (1962b). Acta derm.-venereol. (Stockh.), 42, 305.

Guthe, T. (1961). Bull. Wld Hlth Org., 24, 297.

Hilton, A. L. (1959), Brit. J. vener. Dis., 35, 249.

Hirsch, H. A., Finland, M., and Wilcox, C. (1960). Amer. J. med. Sci., 239, 41.

Jensen, T. (1953). Brit. J. vener. Dis., 29, 222.

King, A. J. (1960). Ibid., 36, 34.

and Nicol, C. S. (1962). Bull. Wld Hlth Org., 24, 373.

Knight, G. (1958). Brit. J. vener. Dis., 34, 223.

Love, B. D., and Finland, M. (1955). Arch. intern. Med., 95, 66.

M.R.C. Interim Report (1961). Lancet, 2, 226.

Miller, C. P., and Bohnhoff, M. (1945). Proc. Soc. exp. Biol. (N.Y.), 60, 354. (1946). J. Amer. med. Ass., 130, 485.

Moore, J. E. (1949). Brit. J. vener. Dis., 25, 169.

Rees, E. (1952). Ibid., 28, 115.

Reyn, A., Korner, B., and Bentzon, M. W. (1958). Ibid., 34, 227.

(1961). Ibid., 37, 145.

Schmidt, H., and Larsen, S. O. (1962). Acta derm.venereol. (Stockh.), 42, 294.

Scott, J., and Stone, A. H. (1966). Brit. J. vener. Dis., 42, 103.

Thayer, J. D., Field, F. W., Magnuson, H. J., and Garson, W. (1957). Antibiot. and Chemother., 7, 306.

,$- \frac{306 .}{(1961)}$ Perry, M. I., Martin, J. E., and Garson, W. (1961). Bull. Wld Hlth Org., 24, 327.

Wilkinson, A. E. (1952). Brit. J. vener. Dis., 28, 24.

Willcox, R. R. (1962). Brit. J. clin. Pract., 16, 587.

Zimmerman, M. C. (1958). "Antibiotics Annual, 19571958,', p.312. New York.

Rechutes de la blennorragie après le traitement avec de la pénicilline et de la streptomycine

\section{RÉSUMÉ}

(1) Des 2,258 hommes souffrant d'urétrite blennorragique traités avec une seule injection de 600,000 unités de 
procaine pénicilline, 11,4 pour cent ont rechuté après le traitement. De nouveau traités avec 2,5 mega-unités de "Triplopène" le taux cumulatif de guérison a été de 98,5 pour cent tandis qu'un troisième traitement avec 5 méga-unités données deux fois par jour pendant trois jours a produit un taux cumulatif de guérison de 100 pour cent.

(2) Des 1,841 hommes souffrant d'urétrite blennorragique traités par une ou deux injections intra musculaires d'un gramme de streptomycine 19,1 pour cent ont rechuté après ce traitement. Un mélange d'un sulfamide et de streptomycine n'a pas donné de meilleurs résultats que la streptomycine seule.

(3) Il y a eu de grandes variations à différents moments dans la proportion des malades qui ont rechuté avec la procaine penicilline et la streptomycine mais il n'y a pas eu des variations régulières selon les saisons. Les réchutés avaient tendance à se grouper et n'avaient aucune relation avec l'introduction d'une nouvelle série de l'antibiotique.

(4) Les patients qui avaient eu leur blennorragie soignée précédemment avec de la pénicilline ou la streptomycine (avec ou sans succès) n'ont pas montré aucune tendance particulière d'insuccès avec le même antibiotique à une réinfection subséquente.

(5) Aucun groupe racial ou groupe d'âges dans cette étude n'a montré une augumentation d'une tendance à rechuter après le traitement.

(6) Les hommes souffrant de l'urétrite blennorragique qui n'avaient pas été guéris par la streptomycine ont généralement rechuté immédiatement (i.e. sans un intervalle sans symptômes et sans absence de gonocoques) tandis qu'avec de la procaine pénicilline la majorité des hommes qui ont rechuté l'ont fait pendant le 2ème et le 7ème jour du traitement.

(7) Il n'y a eu aucune corrélation chez les hommes souffrant d'urétiite blennorragique entre l'intervalle du traitement avec de la procaine pénicilline et de la rechuté et la sensibilité à la pénicilline in vitro du gonocoque isolé.

(8) 89 pour cent des gonocoques isolés des hommes qui ont rechuté après traitement par la procaine pénicilline ont été résistants à la streptomycine. Les infections gonococciques avec des souches sensibles à la streptomycine ont généralement répondu au traitement avec de la procaine pénicilline tandis que les infections causées par des souches résistantes à la streptomycine n'ont pas souvent répondu au traitement.

(9) Le taux d'insuccès avec la procaine pénicilline chez les hommes souffrant d'urétrite blennorragique qui n'avaient pas déjâ répondu à la streptomycine était trois fois plus fort que le taux d'insuccès avec la procaine pénicilline chez les patients qui n'avaient pas été sélectionnés.

(10) Pour la blennorragie transmise hetero-sexuellement traitée avec la procaine pénicilline et la streptomycine la non-réussite du traitement chez un patient a indiqué une probabilité bien nette ( 84 à 91 pour cent) que le traitement avec le même médicament et le même dosage n'aurait pas de succès chez le partenaire. Cependant si un des partenaires n'a pas déjâ répondu au traitement le même traitement ne devrait pas être donné à l'autre partenaire.

(11) Dans les cas de blennorragie transmise homosexuellement et traités avec 1 gramme de streptomycine, le taux d'insuccès à propos de la rectite et de l'urétrite a été semblable. Quand 600,000 unités de procaine pénicilline ont été employé le taux d'insuccès dans la rectite blennorragique était deux fois plus élevé que celui de l'urétrite blennorragique acquise homo-sexuellement. Chez certains partenaires homosexuels le traitement avec 600,000 unités de procaine pénicilline a guéri le partenaire actif souffrant d'urétrite blennorragique mais n'a pas réussi à guérir le partenaire passif souffrant d'une rectite blennorragique. En se servant de la streptomycine chez des partenaires semblables les deux partenaires ont été ou guéris ou ont rechuté. De ce fait la rectite blennorragique devrait être soignée avec une plus forte dose de pénicilline ou avec un médicament différent.

(12) Chez plus de la moitié des femmes souffrant de blennorragie qui n'avaient pas été guéries avec de la procaine pénicilline le diagnostic d'une rechuté ne pouvait être fait que par culture seulement. Des fréquents examens par culture sont ainsi essentiels dans la surveillance de la blennorragie chez la femme.

(13) Une combinaison de procaine pénicilline et de probénécide suivie de pénicillinase a produit un niveau sérique de pénicilline de plus d'une unité $/ \mathrm{ml}$. pendant 24 heures et le niveau a alors subi une chute rapide jusqu'à zéro. Un tel traitement aurait des avantages théoriques dans le traitement de la blennorragie mais pour des raisons pratiques il ne peut être recommandé. 